Gut, 1971, 12, 717-720

\title{
Further studies on streptozotocin therapy for a multiple-hormone-producing islet cell carcinoma
}

\author{
IAIN M. MURRAY-LYON, J. CASSAR, R. COULSON, ROGER WILLIAMS, \\ P. C. GANGULI, J. C. EDWARDS, AND KEITH W. TAYLOR
}

From King's College Hospital, London, the Medical Research Council Clinical Endocrinology Research Unit, Edinburgh, and the Department of Biological Sciences, University of Sussex

SUMMARY A patient with a multiple-hormone-producing islet cell carcinoma, who had previously been successfully treated with streptozotocin, was given three further infusions of this drug because of the redevelopment of gastric hypersecretion. Although some evidence of damage to the gastrinsecreting cells was obtained, the fasting plasma gastrin was not significantly altered and the patient died from a perforated duodenal ulcer. Serum insulin levels were considerably reduced and the patient became mildly diabetic but the main complication of treatment was a severe though reversible renal tubular defect. At necropsy considerable quantities of gastrin, but low levels of insulin and glucagon were extracted from a tumour metastasis.

We have previously reported the use of streptozotocin in the successful treatment of a patient with intractable hypoglycaemia due to a malignant islet cell tumour (Murray-Lyon, Eddleston, Williams, Brown, Hogbin, Bennett, Edwards, and Taylor, 1968). In this paper we describe the subsequent course of our patient and the metabolic effects of further streptozotocin therapy which was followed by temporary but severe toxic renal damage.

\section{Case Report}

This 59-year-old housewife, who first presented with hypoglycaemia in October 1967 and was later found to have hepatic metastases, received three infusions of streptozotocin (1.5, 3, and $4 \mathrm{~g}$ ) between April and May 1968. Symptoms of hypoglycaemia were abolished and the high serum insulin levels returned to normal as did the raised serum levels of gastrin (associated with marked gastric hypersecretion) and glucagon. From that time until February 1969 she remained entirely well without treatment. She then started to pass up to four watery stools daily, became anorexic, and vomited every few days. When readmitted to hospital in April 1969, the blood count, blood urea and electrolytes, plasma cortisol, liver function tests, and urine 5-hydroxy-indoleacetic acid were all normal. The filling defects in the liver scan had increased in size and a barium meal showed marked rugosity of the mucosa of the

Received for publication 6 July 1971. stomach, duodenum, and jejunum with an ulcer crater in the second part of the duodenum.

A maximal histamine test showed the redevelopment of marked gastric hypersecretion (Table), and bioassay of a fasting serum sample using a modification of the technique of Ghosh and Schild (1958) gave a positive response equivalent to at least $0.5 \mu \mathrm{g}$ gastrin II $/ \mathrm{ml}$. Gastrin was also assayed by the radoimmunoassay method of Ganguli and Hunter (1971) and on two occasions after an overnight fast the plasma level was markedly elevated, at 16.8 and $43.8 \mathrm{ng} / \mathrm{ml}$ (normal range $101 \pm \mathrm{SE} 6 \mathrm{pg} / \mathrm{ml}$ ). The standard curve for gastrin $I$ and the dilution curves for the patient's plasma and a buffered phosphatesaline extract of the tumour tissue subsequently obtained were linear and parallel to each other.

\section{Further Treatment with Streptozotocin}

Because the previous treatment had controlled the excess production of gastrin, three further infusions of streptozotocin were given. A $3 \mathrm{~g}$ dose (dissolved in $200 \mathrm{ml} \mathrm{N}$ saline and infused over 20 minutes) on 1 May 1969 was followed by some improvement in the troublesome diarrhoea but she continued to feel nauseated and unwell and further doses of 4.5 and $6 \mathrm{~g}$ were infused in a similar manner on 6 and 23 June respectively.

EFFECTS ON GASTRIN AND GASTRIC SECRETION

Following each of these three infusions there was a 


\begin{tabular}{|c|c|c|c|c|c|c|c|c|c|c|c|}
\hline \multirow[t]{2}{*}{ Date of Test } & \multirow{2}{*}{$\begin{array}{l}\text { Relation to } \\
\text { Streptozotocin } \\
\text { Infusion }\end{array}$} & \multirow{2}{*}{$\begin{array}{l}\text { Basal Acid } \\
\text { Output } \\
\text { (m-equiv/hour) }\end{array}$} & \multirow{2}{*}{$\begin{array}{l}\text { Posthistamine } \\
\text { Maximal Output } \\
\text { (m-equiv/hour) }\end{array}$} & \multicolumn{4}{|c|}{ Blood Gluccse $(\mathrm{mg} / 100 \mathrm{ml})$} & \multicolumn{4}{|c|}{ Serum Insulin $(u U / m l)$} \\
\hline & & & & $\begin{array}{l}0 \\
\text { (fasting) }\end{array}$ & $\begin{array}{l}30 \\
(\min )\end{array}$ & $\begin{array}{l}60 \\
(\min )\end{array}$ & $\begin{array}{l}120 \\
(\min )\end{array}$ & $\begin{array}{l}0 \\
\text { (fasting) }\end{array}$ & $\begin{array}{l}30 \\
(\min )\end{array}$ & $\begin{array}{l}60 \\
(\min )\end{array}$ & $\begin{array}{l}120 \\
\text { (min) }\end{array}$ \\
\hline \multirow{6}{*}{$\begin{array}{l}\text { August } 121968 \\
\text { April } 16 \text { and } 181969 \\
\text { May } 30 \text { and June } 4 \\
1969 \\
\text { June } 10 \text { and } 131969 \\
\text { August } 41969\end{array}$} & \multirow{6}{*}{$\begin{array}{l}\text { Four weeks after } \\
\text { first dose } \\
\text { One week after } \\
\text { second dose } \\
\text { Six weeks after } \\
\text { third dose }\end{array}$} & 2.5 & $28 \cdot 7$ & & & & & & & & \\
\hline & & 72 & $76 \cdot 5$ & 86 & 228 & 219 & 133 & 36 & 168 & 168 & 118 \\
\hline & & 64.9 & $70 \cdot 8$ & 82 & 168 & 185 & 106 & 71 & 122 & 108 & 88 \\
\hline & & & $50 \cdot 7$ & 85 & 181 & 198 & 124 & 58 & 89 & 00 & 80 \\
\hline & & 40.4 & 30. & 0.0 & 101 & 190 & 124 & 30 & 88 & 98 & 80 \\
\hline & & & & 84 & 174 & 192 & 233 & 14 & 17 & 20 & 44 \\
\hline
\end{tabular}

Table Data relating to gastric acid secretion and to blood glucose and serum insulin levels during $50 \mathrm{~g}$ glucose tolerance tests from time of previous report (August 1968) ${ }^{1}$

${ }^{1}$ Blood glucose was measured by the method of Hugget $t$ and Nixon and serum insulin by minor modifications of the method of Hales and Randle.

fall in plasma gastrin concentration at $\mathbf{3 0}$ minutes followed by a rise to about twice the pre-infusion level at 80 minutes and subsequently a gradual return to the initial level (Fig. 1). Gastric acidity measurements after the first two doses were apparently unaffected (Table) as was the markedly increased plasma gastrin demonstrated by serial bioassay and radioimmunoassay estimations. The absolute levels according to the latter technique were fairly constant between infusions and after the course of treatment (31.9-47.9 $\mathrm{ng}$ gastrin $\mathrm{I} / \mathrm{ml}$ plasma).

\section{EFFECTS ON GLUCOSE AND INSULIN}

METABOLISM

The first two infusions had no significant effect on plasma glucose or insulin levels but during the third infusion there was a sharp rise in insulin level (Fig. 2). The plasma free fatty acids fell significantly following the second and third infusions and on both
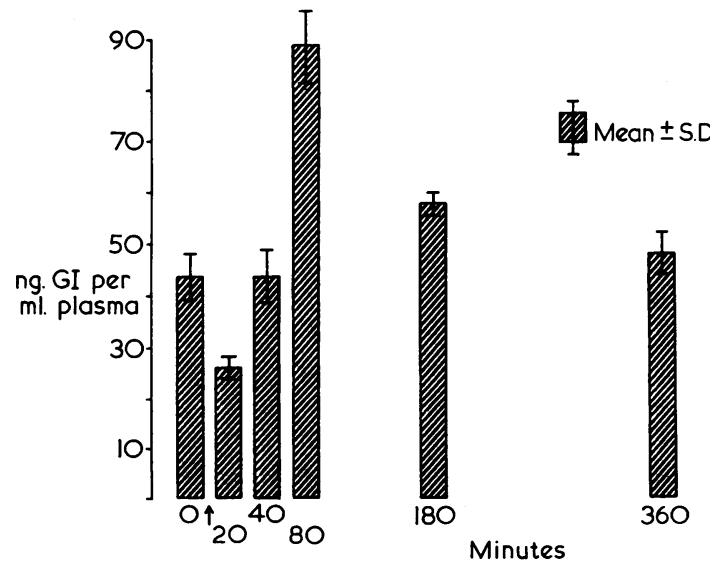

Fig. 1 Plasma gastrin levels determined by radioimmunoassay before and at intervals after infusion of 3 g streptozotocin. occasions there was a temporary rise in lactate and pyruvate (Fig. 2). The level of aceto-acetate rose during the two hours of observation after the second and third infusions and fell briefly immediately following the third infusion (Fig. 2).

On admission the oral glucose tolerance test indicated slight impairment of glucose tolerance with raised blood glucose levels despite the increased

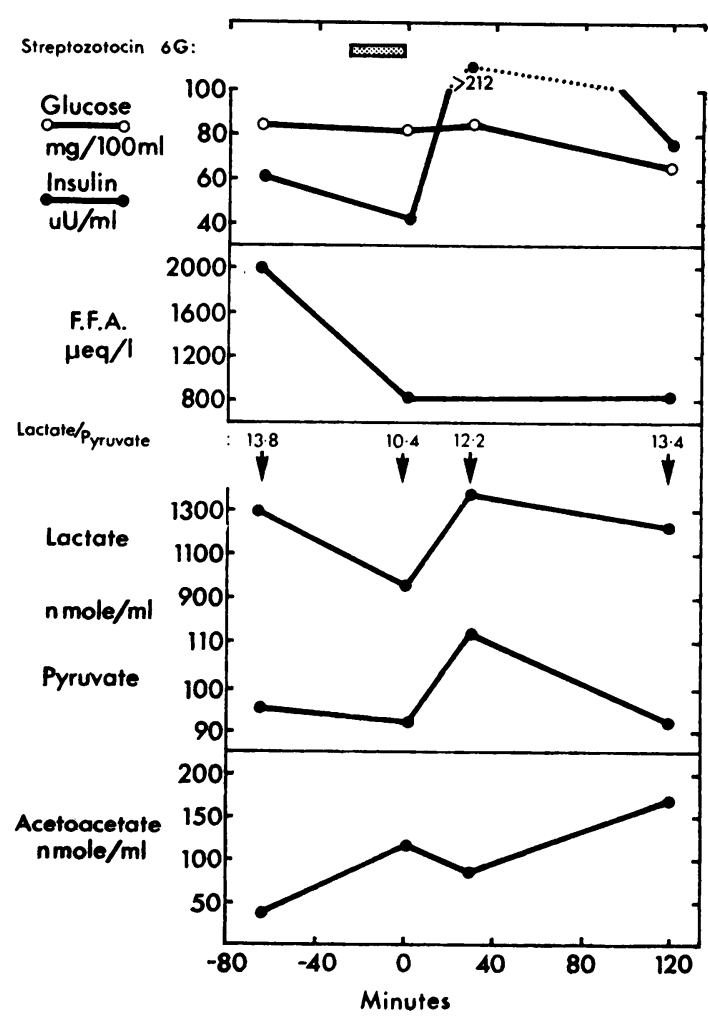

Fig. 2 Serum insulin, blood glucose, lactate, pyruvate, lactate-pyruvate ratio and acetoacetate before and after the third infusion of streptozotocin. 
fasting insulin levels. Subsequent tests following the first two infusions showed somewhat lower blood glucose levels (Table) but after the third dose of streptozotocin there was marked deterioration in glucose tolerance with accompanying impairment in the plasma insulin response.

\section{DEVELOPMENT OF RENAL TUBULAR DEFECT}

A fall in serum potassium (2.3 to 3.7 m-equiv/l) and bicarbonate (12 to $21 \mathrm{~m}$-equiv/l) were noted following the second infusion but severe polyuria with polydipsia did not start until 10 days after the third dose of streptozotocin. Urine output varied between 2.5 and 5.51 per 24 hours when intravenous fluid replacement was required to maintain fluid balance. Urine glucose seldom exceeded $0.25 \mathrm{~g} / 100 \mathrm{ml}$ and hypercalcaemia as a cause of the polyuria was also excluded. Excess renal loss of potassium was demonstrated with excretions of 93 and 70 m-equiv per 24 hours despite serum levels of $2 \cdot 8$ and $3 \cdot 1$ m-equiv/1. The urine amino-acid chromatograms, however, showed a normal pattern. The osmolality of plasma during free water ingestion was 285 $\mathrm{mOsm} / \mathrm{kg}$ (normal 276-294 $\mathrm{mOsm} / \mathrm{kg}$ ) and that of urine $150 \mathrm{mOsm} / \mathrm{kg}$. When deprived of water she passed 2.9 litres of urine over a 14-hour period but urine flow never fell below $2 \mathrm{ml}$ per minute, and, although plasma osmolality rose to $295 \mathrm{mOsm} / \mathrm{kg}$, the highest reading for urine was $227 \mathrm{mOsm} / \mathrm{kg}$.

She was treated with lysine-8-vasopressin nasal spray, intramuscular pitressin tannate in oil, and chlorothiazide but without significant effect. Her improvement subsequently in early September when urine output decreased and the serum potassium level rose to normal was probably spontaneous.

\section{Final Illness}

On 14 September her condition suddenly deteriorated and she died 24 hours later. Necropsy revealed generalized peritonitis due to perforation of a duodenal ulcer. There were numerous hepatic metastases and the histological appearances were the same as in the liver biopsy specimen of 1968 already reported. No other endocrine tumours were found and there were no cerebral metastases. The hypothalmic nuclei were normal (Dr D. Doyle) and histological examination of the kidneys showed autolytic changes only.

One of the hepatic metastases was snap frozen in liquid nitrogen. Radioimmunoassay for gastrin after extraction in buffered phosphate-saline gave a mean value of 708 (SD \pm 66$) \mathrm{ng} / \mathrm{g}$ wet weight tumour tissue. Radioimmunoassay for glucagon (Edwards, Howell, and Taylor, 1970) and insulin
(Hales and Randle, 1963), after extraction by the method of Kenny (1955), gave values of $0.015 \mu \mathrm{g} / \mathrm{g}$ and $6 \mathrm{mU} / \mathrm{g}$ wet weight of tumour respectively.

\section{Discussion}

Since our initial report of this patient other successfully treated cases have been described (Arnould, Ooms, and Bastenie, 1969; Sadoff, 1969; Stanley, Marks, Kreel, and McIntyre, 1970; Blackard, Garcia, and Brown, 1970; Taylor, Schwartz, Zannini, and Ryan, 1970). Clinically her remission lasted only eight months and although excess insulin production again developed there were no symptoms of hypoglycaemia and it was the effects of gastric hypersecretion which dominated the clinical picture. Plasma glucagon was not measured during the second admission but our original premise, that the one tumour was producing insulin, gastrin, and glucagon, was borne out by the necropsy findings and by the extraction of all three hormones from a metastasis. The levels of insulin-like and glucagon-like immunoreactivity in this tumour were similar to those found in other non- $\beta$ islet cell tumours by Unger and Eisentraut (1967) and are between 100 and 1,000 times lower than the levels found in normal pancreatic tissue.

The first course of streptozotocin in 1968 reduced serum gastrin levels and abolished gastric hypersecretion but further doses were clearly ineffective. Although the transient rise in plasma gastrin concentration immediately after each infusion suggests some damage to the gastrin-secreting cells, subsequent measurement of fasting samples showed the gastrin level to be unaltered.

Similarly the increase in serum insulin concentration at the end of the third infusion may have been due to release of insulin from damaged beta cells (Junod, Lambert, Orci, Pictet, Gonet, and Renold, 1967). There was no accompanying fall in plasma glucose which may have been related to an effect of streptozotocin which has been described in non-fasted rats, namely, the production of acute hyperglycaemia (Junod, Lambert, Stauffacher, and Renold, 1969). Alternatively, the insulin released may have been less active biologically than normal (Goldsmith, Yalow, and Berson, 1969). The absence of an increase after the previous smaller infusions suggests either that this is a dose-related response or that the effects are cumulative (Junod et al, 1969). Only after the third dose was the insulin response to a glucose load impaired and at this time fasting levels were within the normal range. The fall in plasma free fatty acid following the second and third infusions could have been due to increased uptake by adipose tissue, diminished lipolysis, or increased 
breakdown of free fatty acid in the liver. The latter possibility is compatible with the increased levels of acetoacetate.

Structural changes have been described in the renal tubules of animals given streptozotocin(Arison, Ciaccio, Glitzer, Cassaro, and Pruss, 1967) and Sadoff (1969) and Stanley, Marks, Kreel, and McIntyre (1970) have reported aminoaciduria, glycosuria, and renal tubular acidosis, and one patient developed acute tubular necrosis. Some renal damage may have followed the second infusion in our patient and the diabetes insipidus which followed the third dose was almost certainly renal in origin as it was associated with failure of renal potassium conservation and the water loss was unaffected by posterior pituitary hormone (Relman and Schwartz, 1967).

We thank Dr K. R. L. Mansford for helpful advice, Mr B. M. Hogbin for carrying out the biological assays of gastrin, Miss P. Owen for the free fatty acid estimations, and the Medical Research Council for support to R.W. and P.C.G.

\section{References}

Arison, R. N., Ciaccio, E. I., Glitzer, M. S., Cassaro, J. A., and Pruss, M. P. (1967). Light and electron microscopy of lesions in rats rendered diabetic with streptozotocin. Diabetes, 16, 51-56.

Arnould, Y., Ooms, H. A., and Bastenie, P. A. (1969). Treatment of insulinoma with Streptozotocin. Lancet, 1, 1210-1211.

Blackard, W. G., Garcia, A. R., and Brown, C. L., Jr. (1970). Effect of streptozotocin on qualitative aspects of plasma insulin in a patient with a malignant islet cell tumour. J. clin. Endocr., 31, 215-219.
Edwards, J. C., Howell, S. L., and Taylor, K. W. (1970). Radioimmunoassay of glucagon released from isolated guinea-pig islets of Langerhans incubated in vitro. Biochim. biophys. Acta (Amst.), 215, 297-309.

Ganguli, P. C., and Hunter, W. M. (1971). Gut, in press.

Ghosh, M. N., and Schild, H. O. (1958). Continuous recording of acid gastric secretion in the rat. Brit. J. Pharmacol., 13, 54-61.

Goldsmith, S. J., Yalow, R. S., and Berson, S. A. (1969). Significance of human plasma insulin sephadex fractions. Diabetes, 18, 834839.

Hales, C. N., and Randle, P. J. (1963). Immunoassay of insulin with insulin-antibody precipitate. Biochem. J., 88, 137-146.

Hugget t, A. St. G., and Nixon, D. A. (1957). Use of glucose oxidase, peroxidase, and $\mathrm{O}$-dianisidine in determination of blood and urinary glucose. Lancet, 2, 368-370.

Junod, A., Lambert, A. E., Orci, L., Pictet, R., Gonet, A. E., and Renold, A. E. (1967). Studies of the diabetigenic action of streptozotocin. Proc. Soc. exp. Biol. (N.Y.), 126, 201-205.

Junod, A., Lambert, A. E., Stauffacher, W., and Renold, A. E. (1969). Diabetogenic action of streptozotocin: relationship of dose to metabolic response. J. clin. Invest., 48, 2129-2139.

Kenny, A. J. (1955). Extractable glucagon of the human pancreas. J. clin. Endocr., 15, 1089-1105.

Murray-Lyon, I. M., Eddleston, A. L. W. F., Williams, R., Brown, M., Hogbin, B. M., Bennett, A., Edwards, J. C., and Taylor, K. W. (1968). Treatment of multiple-hormone-producing malignant islet-cell tumour with streptozotocin. Lancet, 2 , 895-898.

Relman, A. S., and Schwartz, W. B. (1967). Effect of electrolyte disorders on renal structure and function. In Renal Disease, 2nd ed., Ch. 29 , p. 754 , edited by D. A. K. Black. Blackwell, Oxford.

Sadoff, L. (1969). Effects of streptozotocin in a patient with islet cell carcinoma. Diabetes, 18, 675-678.

Stanley, N. N., Marks, V., Kreel, L., and McIntyre, N. (1970). Streptozotocin treatment of malignant islet cell tumour. Brit. med. J., 3, 562-563.

Taylor, S. G. III, Schwartz, T. B., Zannini, J. J., and Ryan, W. G. (1970). Streptozotocin therapy for metastatic insulinoma. Arch. intern. Med., 126, 654-657.

Ungar, R. H., and Eisentraut, A. M. (1967). Glucagon. In Hormones in Blood, 2nd ed., Vol. 1, ch. 5, edited by C. H. Gray and A. L. Bacharach, p. 122. Academic Press, London and New York. 